\title{
THE HISTORY OF A PORTION OF YAMPA RIVER, COLORADO, AND ITS POSSIBLE BEARING ON THAT OF GREEN RIVER.
}

Ву Е. Т. НАNCOCK.

Few regions offer more interesting geologic problems relating to drainage than the Uinta Mountains, in Utah and Colorado, and the area immediately east of them. In fact, the writer's attention was primarily attracted to this field by the diversity of opinion regarding the antecedent origin of Green River. Although the present paper deals mainly with that portion of Yampa River aast of Juniper Mountain, the conclusions reached are believed to have a definite bearing on the Green River problem itself. The paper is introduced by a brief discussion of the structural features of the region east of the Uinta Mountains, for a clear understanding of the relation of the minor uplifts to the great Uinta fold will better enable the reader to appreciate the possible bearing which the writer's conclusions may have in the solution of that problem.

The main range of the Uinta Mountains is a broad, flat-topped anticline, which has an easterly trend and a length of over 150 miles and which separates the Green River Basin on the north from the Uinta Basin on the south. The conspicuous portion of the Uinta fold terminates in northwestern Colorado, but along the continuation of its axis to the east lies a long, gentle anticline which reaches the foothills of the Park Range. This anticline was called by White " "the inceptive portion of the Uinta fold." The axis of the anticline is coincident with the low, broad valley known as Axial Basin, and in a recent report Gale ${ }^{2}$ refers to it as the Axial Basin anticline. According to White, along the eastern end of the main fold the strata abruptly dip east beneath the younger Tertiary beds. Upon the Axial Basin anticline have been developed two local uplifts wbich he called the Junction Mountain upthrust and the Yampa Mountain upthrust. These he regarded as the result of a locally intensified application of the same force by which the main fold was elevated. The peculiar relation which exists between these two "upthrusts" and the course of Yampa River renders it necessary that the reader shall clearly understand their character.

According to White, ${ }^{3}$ the western base of Junction Mountain is 2 or 3 miles east of the east end of the main Uinta fold. There the same strata that plunge down on the east side of the Uinta Range rise even more abruptly, and the Paleozoic formations which constitute the high mountain peaks of the Uinta Range are uplifted to a maximum height of nearly 2,000 feet above the surrounding lowland. White says that the strata involved in the Junction Mountain uplift occupy an elongate oval area, the longer diameter of which is nearly 12 miles and the shorter about 4 miles in length. The direction of the longer diameter, being approximately northwest, is obliquely transverse to the general direction of the axis of the main fold. White ${ }^{4}$ describes Juniper Mountain (then known as Yampa Mountain) as another "upthrust" of the Paleozoic formations which also rises directly upon the axis of the inceptive fold. It is likewise oval in outline, and has a longer diameter of about 7 miles and a shorter diameter of less than 4 miles. The longer diameter is almost at right angles with that of the Junction Mountain "upthrust" and nearly transverse with the inceptive portion of the Uinta axis. The Uinta Mountain uplift involves many thousand feet of sedimentary rocks of Paleozoic, Mesozoic, and Cenozoic age. According to Powell, ${ }^{5}$ the great mass of the Uinta Range is composed of

1 White, C. A., On the geology and physiography of a portion of northwestern Colorado and adjacent parts of Utah and Wyoming: U.S. Geol. Survey Ninth Ann. Rept., p. 692, 1889.

2 Gale, H. S., Coal fields of northwestern Colorado and northeastern Utah: U. S. Geol. Survey Bull. 415, p. 97, 1910.

3 White, C. A., op. cit., p. 701.

4 Idem, p. 702.

5 Powell, J. W., Report on the geology of the eastern portion of the Uinta Mountains and a region of country adjacent thereto, p. $141,1876$. 
sandstones of what he called the "Uinta group." The map given by White, ${ }^{1}$ compiled in part from the published maps of Powell, Hayden, and King, shows the Junction Mountain and Juniper Mountain uplifts as being composed mainly of carboniferous beds, with a small area of the so-called "Uinta" quartzite outcropping near the summit in each uplift. Clearly, then, the only essential difference between the two local uplifts and the main Uinta Mountains uplift is one of magnitude. The relation of some of the recent Tertiary formations to these uplifts will be discussed later. Readers desiring a terse description of the course of Green River through the Uinta Mountains are referred to White's report. ${ }^{2}$

The course of Green River across the uplifted Paleozoic rocks of the Uinta Range with entire disregard for structure is so remarkable as to arrest the attention of every observer. The peculiar course of the river is even more striking in view of the fact that apparently it might easily have gone east of the uplift, making its channel in the soft formations of the lowland. But the course of Green River through the Uinta Range is no more remarkable than that of the Yampa, which empties into Green River from the east, in its relation to the Junction Mountain and Juniper Mountain uplifts. Yampa River has its origin among the mountains of the Park Range, where its numerous tributaries flow as turbulent streams through rocky defiles and narrow valleys. Emerging from the foothills of the Park Range, it enters a more or less open country and traverses the formations involved in the Axial Basin anticline and the Juniper uplift with apparent disregard for rock structure. Throughout most of this part of its course, which leads diagonally across the strike of the beds upturned along the north side of the Axial Basin anticline, it has developed well-defined intrenched meanders. Finally it reaches the hard Paleozoic metamorphosed limestones and sandstones of Juniper Mountain, where, instead of continuing in the soft beds around the north end of the uplift, it swings southward and cuts its way by means of a short canyon through the hard Paleozoic rocks that form the north flank of the uplift. From Juniper Mountain the river flows quietly over the lowlands - of Axial Basin to Junction Mountain, which it cuts through in a similar manner. The opportunity seems to have been especially favorable for the Yampa to join Snake River near the north end of Junction Mountain, for it trends in that direction throughout more than half its course after leaving Juniper Mountain. Instead of that, however, it makes a distinct bend southwestward to Junction Mountain, and without swerving to the right or left cuts through the upturned strata of hard rock in a narrow canyon, the almost perpendicular walls of which, according to White, reach a maximum height of 1,000 to 1,200 feet above the lowland at either end of the canyon. Beyond Junction Mountain the river flows quietly for about 10 miles through Lily Park. Then instead of joining Green River by way of the lowland on either the north or the south side of the Uinta Range it boldly enters the east end of the range itself by crossing the upturned strata, as in the two uplifts previously described. The remainder of the river's course is through a narrow canyon, in places 1,200 feet deep, which opens into the canyon of Green River northeast of the point where that river emerges on the south side of the Uinta Range. (See Pl. XX.)

As an introduction to the discussion of the drainage east of Juniper Mountain, the views that have been held by some of the earlier geologists regarding the origin of Green and Yampa rivers will be very briefly stated. Powell, ${ }^{3}$ as a result of his early explorations, says that the proof is abundant that Green River cut its own channel and that it was running before the mountains were formed- "that the river did not cut its way down through the mountains from a height of many thousand feet above its present site, but, having an elevation differing but little perhaps from what it now has, as the fold was lifted it cleared away the obstruction by cutting a canyon, and the walls were thus elevated on either side." The antecedent origin of certain of the river valleys of the great Rocky Mountain region had previously been suggested by Hayden. ${ }^{4}$ In a paper read in May, 1896 , Irving ${ }^{5}$ says: "It is a fact no longer disputed that these

\footnotetext{
1 White, C. A., op. cit., p. 684.

2 Idem, p. 707.

3 Powell, J. W., Exploration of the Colorado River of the West and its tributaries, p. 152, 1875.

${ }^{4}$ Hayden, F. V., Am. Jour. Sci., vol. 33, May, 1862; U. S. Geol. Survey Terr. Sixth Ann. Rept., for 1872, p. 85, 1873.

${ }^{5}$ Irving, J. D., The stratigraphical relations of the Browns Park beds of Utah: New York Acad. Sci. Trans., vol. 15, p. 258, 1896.
} 


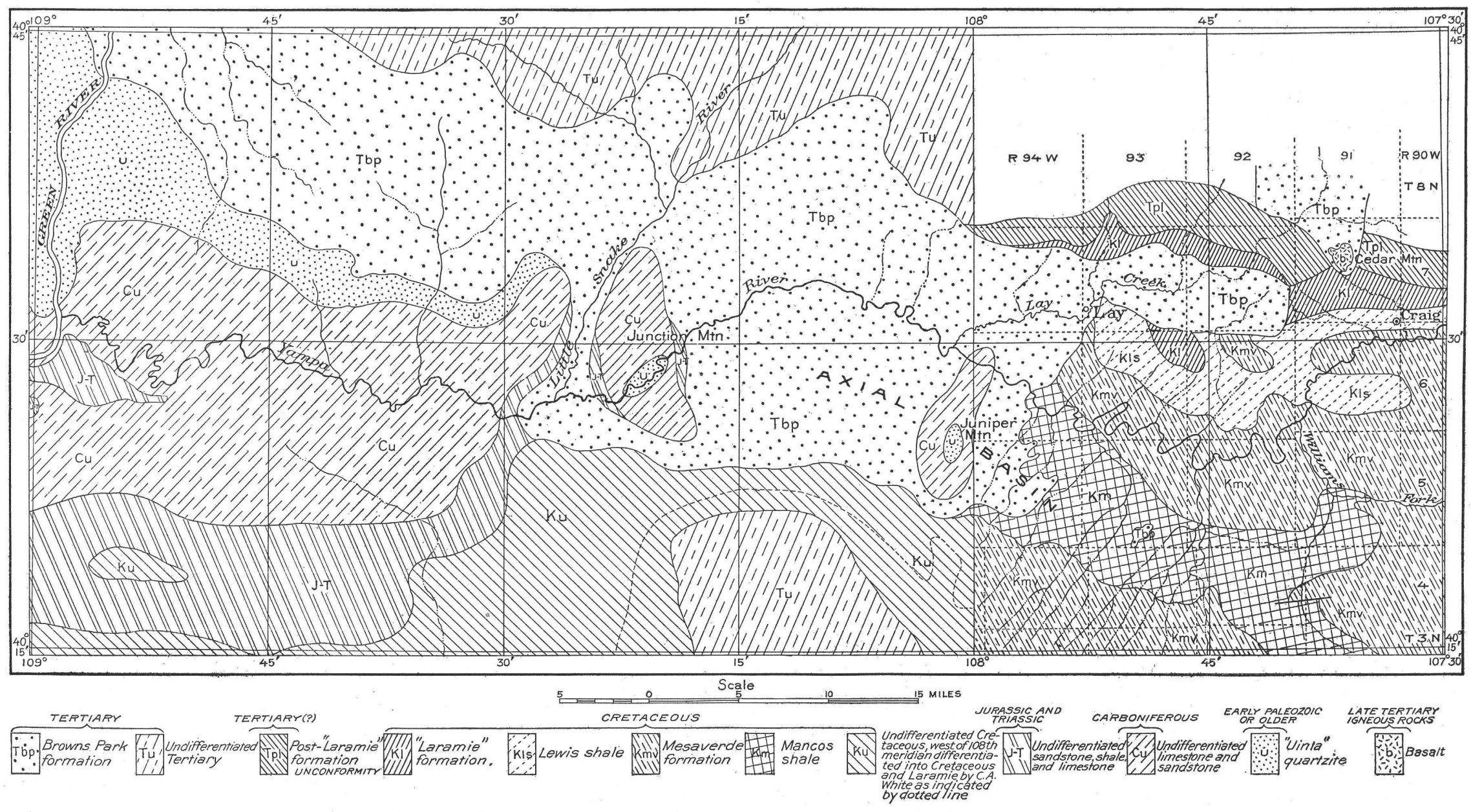

MAP SHOWING THE COURSE OF YAMPA RIVER, IN MOFFAT COUNTY, COLO., FROM GREEN RIVER EAST TO $107^{\circ} 30^{\prime}$ WEST LONGITUDE. 

deep canyons in the quartzite, by which the river crosses the mountains, were first established in the softer overlying formations and that these formations furnished much of the corrosive material by means of which the harder rocks were cut away." In 1897 Davis, ${ }^{1}$ in commenting on the above-quoted statement of Irving, said:

It is not clear whether the overlying formations here mentioned were higher members of the Uinta arch or unconformably overlying Tertiaries. If the former, the writer would support Powell's explanation of the antecedent origin of the river; if the latter, he would support Emmons's view that the river is of superposed origin. In either case discussion on the question is hardly closed. Indeed, considering how frequently the Green is referred to as an antecedent river, it is remarkable that so little attention is given to the doubts that have been expressed regarding that manner of origin and to the difficulties that such an origin involves.

Davis also calls attention to the fact that two recent textbooks on geology ${ }^{2}$ credit the antecedent explanation. Davis ${ }^{3}$ himself says:

The Green River was unquestionably laked by the uplift of the Uinta Range, and to this extent it is a defeated and not an antecedent river. Between its two meridional portions, north and south of the range, the river makes a great bend to the east, turning from the higher toward the lower part of the uplift-a remarkable coincidence if this was an antecedent turn.

A few months later Emmons, ${ }^{4}$ referring to the above-cited article by Davis, said:

Long before the appearance of the two textbooks he quotes (Tarr and Scott), Le Conte and Geikie had each referred to it as antecedent and illustrating the slow uplift of mountain ranges, in apparent unconsciousness that any other view is possible. Suess, ${ }^{5}$ on the other hand, in his exceedingly careful review of the structure of this region, adopted my view without any reference to that of Powell.

Throughout the remainder of his article Emmons points out some of the difficulties involved in the antecedent origin advanced by Powell, and finally closes ${ }^{6}$ by saying:

I have for a long time been hoping, and still hope, that some other geologist may make a more thorough examination than I was able to make at that time and determine the nature and extent of this singular formation [referring to the Bishop ("Wyoming") conglomerate], which has never been satisfactorily accounted for. Whatever may be the outcome of such an examination, it would seem proper that the antedecent origin of this river should be held in abeyance until some positive evidence of it can be furnished.

White, ${ }^{7}$ in his concluding remarks on the geology of northwestern Colorado, lays especial emphasis on the antecedent origin of Green and Yampa rivers. In order that his views on the origin of Yampa River, as related to the Junction Mountain and Juniper Mountain uplifts, may be clearly understood a passage is quoted directly from his closing remarks:

The factsalready presented show that the elevation of not only the narrowest folds but even that of the two upthrusts which have been described did not cause the rivers under which their elevation began to swerve from their original courses, as the elevation progressed, to the extent of more than a few rods. This fact is exemplified in Split Mountain, where Green River cuts a short deep canyon through that prominent spur of Yampa Plateau; but it is more conspicuously shown where Yampa River traverses both the Junction and Yampa [Juniper] Mountain upthrusts.

The writer's field observations during the last two years lead to conclusions that are not wholly in accord with those of White relative to the antecedent origin of Yampa River where it cuts its narrow canyon through Juniper Mountain. The field observations opposed to the view of antecedent origin are briefly as follows:

The main portion of the mountain is composed of sandstone and hard red quartzite, including layers of conglomerate. This formation was mapped by White as equivalent to that forming the core of Junction Mountain and also to the typical quartzite and sandstone forming the main core of the Uinta Range. The summit and northern flank of the mountain are composed of metamorphosed limestones and sandstones interbedded. In passing east up Yampa River as far as the Government bridge, and thence northeast and finally north for several miles, one crosses approximately at right angles to the strike the same formations that

1 Davis, W. M., Current notes on physiography: Science, new ser., vol. 5, p. 647, 1897.

2 Tarr, R. S., Elementary geology, p. 319, New York, 1897. Scott, W. B., An introduction to geology, p. 325, New York, 1897.

${ }^{3}$ Davis, W. M., op. cit., pp. 647-648.

${ }^{4}$ Emmons, S. F., Origin of Green River: Science, new ser., vol. 6, p. 19, 1897.

5 Suess, E., Antlitz der Erde, vol. 1, p. 736.

${ }^{6}$ Emmons, S. F., op. cit., p. 21.

7 White, C. A., op. cit., p. 710. 
are involved in the structure of the Axial Basin anticline and the Juniper Mountain uplift. With the exception of that portion of the section included between the Carboniferous beds and the White Cliff sandstone (Jurassic) the entire sequence is well exposed. In all probability from 15,000 to 20,000 feet of beds are included in the section between the top of the "Laramie" and the highest Garboniferous beds exposed. The highest Carboniferous beds exposed at the east end of the canyon dip about $15^{\circ} \mathrm{E}$. From this point the dip increases to $31^{\circ}$ at Juniper Hot Springs, about a mile farther east along the south bank of Yampa River. From the hot springs eastward the dip decreases; for example, the basal beds of the Mesaverde formation about three-quarters of a mile northeast of the Government bridge dip about $15^{\circ} \mathrm{NE}$., and near parallel $40^{\circ} 30^{\prime}$ the Lewis shale dips $6^{\circ}-8^{\circ} \mathrm{NE}$. If the erosion accompanying and following the formation of the Axial Basin anticline and the Juniper Mountain uplift were the last event in the geologic history recorded by the rocks of this region, then the hypothesis of the antecedent origin of the deep canyon through Juniper Mountain might be accepted, but such is not the case. The period of erosion must have been followed by one of subsidence and deposition, for upon the upturned and eroded edges of all the formations studied by the writer, from the Carboniferous to the post-"Laramie," rest a series of horizontal Eocene (?) beds known as the Browns Park formation. The basal beds of this formation where best exposed consist of soft, more or less unconsolidated reddish and yellowish-brown sandstones. These beds usually contain a large amount of conglomerate, the pebbles of which consist of schist, gneiss, coarse and fine grained granite, white and red quartzite, and white and reddish vein quartz. At least 50 feet of such beds lie horizontally above the gently dipping Mancos shale in the bank of the river in the southwest corner of sec. 22 , T. 6 N., R. 94 W. These basal beds grade within a few feet into the overlying soft white sandstone which comprises much the greater part of the formation. Powell ${ }^{1}$ describes the Browns Park "group" as occurring in the valley of Browns Park, a deep basin of erosion in the axis of the Uinta fold, near the east end of the Uinta Range. He says:

Eastward, both on the north and south sides of the area of outcrop, the beds are seen to rest unconformably upon all of the Carboniferous, Mesozoic, and Cenozoic formations previously mentioned. The unconformity with the upper Green River, lower Green River, and Bridger beds is well exhibited in the Dry Mountains in many fine exposures. * * * Conglomerates are found at the base, in some localities having a great development.

White, ${ }^{2}$ who afterward studied the region, described the eastward extension of the beds from Browns Park to Cedar Mountain (then known as Fortification Butte). The map accompanying his report, compiled in part from the published maps of Powell, Hayden, and King, represents these beds as completely surrounding both the Junction Mountain and Yampa [Juniper] Mountain uplifts. They were seen by the writer to be in almost a horizontal position and in direct contact with the Carboniferous beds around the north end of the Juniper Mountain uplift. For about 3 miles east along the river only a narrow belt of the older beds intervenes between the alluvium and the Browns Park formation, which occurs as a thin cap on the low hills. The original thickness and the height to which this formation reached can not be ascertained. The fact, however, that there are points on the Browns Park formation in almost any direction from Juniper Mountain at elevations equal to or greater than that of the highest Carboniferous beds exposed where the river cuts through the mountain strongly indicates that the rocks of the canyon were at one time covered by the Browns Park formation.

Beds resembling in every way the yellowish-brown conglomerate beds at the base of the Browns Park formation in sec. 22, T. 6 N., R. 94 W., cap the hills near the center of Axial Basin, about 12 miles southeast of the east end of the canyon. Gravel, probably resulting from the disintegration of these beds, occurs as a mantle over the upper part of the Mesaverde formation along the high ridge about 7 miles east of the canyon. The easternmost beds of the Browns Park formation observed by the writer occur about half a mile east of Cedar Mountain (Fortification Butte in the old reports). The mountain itself is about 20 miles east and 6 miles north of the canyon and is composed of the Browns Park formation protected by a capping of basalt.

1 Powell, J. W., Report on the geology of the eastern portion of the Uinta Mountains and a region of country adjacent thereto, p. $168,1876$.

2 White, C. A., op. cit., p. 691. 
In 1878 White ${ }^{1}$ maintained that the Browns Park formation could not be of later date than Pliocene Tertiary. In the course of his argument he said:

Furthermore, a remarkably extensive flow of basaltic trap, covering a large region which lies mainly to the eastward but which formerly extended much within the limits of this district, took place after the deposition of the Uinta group [referring to the Browns Park formation] and also after it had suffered displacement and erosion, to some extent at least. This is known to be the case because the trap is found resting upon the unevenly eroded surface of a portion of the Uinta group at Fortification Butte.

In the field season of 1913 the writer succeeded in finding a portion of the sandstone resting upon the basalt at Cedar Mountain and on examination found the sandstone to contain numerous rounded masses of the basalt, indicating that instead of being all much older than the basalt, as White had supposed, it is really in part younger. The fact that deposition of somesandstone beds occurred after the formation of the basalt indicates that the Browns Park formation may have been much thicker than has hitherto been supposed. The elevation of the Browns Park formation on Cedar Mountain is about 860 feet higher than that of the highest Carboniferous beds exposed at the canyon where Yampa River cuts through the north end of Juniper Mountain. The Browns Park formation is also from 800 to 1,000 feet higher than the tops of the ridges across which Yampa River has intrenched its meanders in the rocks of the Mesaverde formation east of Juniper Mountain.

As previously stated, the conspicuous portion of the Uinta fold terminates in northwestern Colorado, but in line with its axis to the east there is a long, gentle anticline which reaches the foothills of the Park Range and which is commonly known as the Axial Basin anticline. Upon this anticline have been developed two distinct uplifts-Junction Mountain and Juniper Mountain. If Yampa River is antecedent its present course must have been established prior to the uplift which resulted in the formation of the Axial Basin anticline and the Junction Mountain and Juniper Mountain uplifts, and it must have lowered its channel through Junction and 'Juniper mountains and intrenched its meanders down through the Mesaverde formation east of Juniper Mountain while the beds were being uplifted into their present position. But attention has already been. called to the fact that during and after the period of upheaval sediments many thousand feet in thickness were eroded almost to a common plane. After the period of erosion the region was submerged and many hundred feet of additional sediments were laid down. Powell, ${ }^{2}$ in his table of the groups of sedimentary strata of the Plateau province, gives the thickness of the Browns Park "group" as 1,800 feet, while White ${ }^{3}$ gives it as 1,200 to 1,800 feet. If Yampa River was antecedent to the formation of the Axial Basin anticline and the Juniper Mountain and Junction Mountain domes, its channel from the east end of the Uinta Mountains to a point as far east as Cedar Mountain-a distance of about 50 miles-would obviously have been completely buried by Browns Park sediments. The river, therefore, could not have maintained its channel, and it is beyond the bounds of probability that, after cutting through the Browns Park sediments, it should have reestablished itself in its original bed and discovered its old canyons through Junction and Juniper mountains.

The distribution of the Browns Park formation and the altitudes at which the beds have been observed make it verry probable that the upper beds of the formation were sufficiently high to cover to a considerable depth all that portion of the Juniper Mountain uplift which is traversed by the canyon, as well as the Cretaceous beds down through which the river has intrenched its meanders. This probability is strengthened by the wide distribution throughout northwestern Colorado and southern Wyoming of beds which have not yet been definitely correlated with the Browns Park formation but which bear a similar relation to the underlying Cretaceous and Tertiary beds.

1 White, C. A., Report on the geology of a portion of northwestern Colorado: U. S. Geol. and Geog. Survey Terr. Tenth Ann. Rept., p. 38, 1878

2 Powell, J. W., Report on the geology of the eastern portion of the Uinta Mountains and a region of country adjacent thereto, p. $40,1876$.

3 White, C. A., On the geology and physiography of a portion of northwestern Colorado and adjacent parts of Utah and Wyoming: U. S. Geol. Survey Ninth Ann. Rept., p. 686, 1889.

$37183^{\circ}-15-13$ 
On the basis of the field observations here briefly recorded the conclusion is reached that Yampa River, instead of being antecedent, is superimposed and that the present course of the river was not established until after the emergence that followed the deposition of the Browns Park sediments. These observations would seem to indicate that the series of events in the development of the present course of the stream was as follows:

After the river had deepened its channel in the Browns Park formation sufficiently to encounter the hard Paleozoic rocks of the Juniper Mountain uplift these rocks acted for a time as a barrier. The gradient of the stream for some distance above the barrier was diminished, and there resulted a condition of local base-leveling. In other words, the stream for some distance above the obstruction approached the condition of old age. After it reached grade and lost the power of degrading its bed, lateral planation resulted in the development of a flood plain upon which the river established its meandering course. Below the barrier the stream was able to deepen its channel much more rapidly in the soft beds of the Browns Park formation. As a result the river developed a steep gradient for some distance below the barrier of uplifted Paleozoic rocks and in all probability formed a series of falls on the lower side of the barrier. Ultimately it succeeded in cutting through the barrier. This being accomplished, the gradient of the channel and the velocity of the water above the hard-rock obstruction were increased, and consequently the river was enabled to intrench its previously established meanders down through the Cretaceous beds along the north limb of the Axial Basin anticline. An appreciable dip was observed at many places where the Browns Park beds are in contact with the older formations. This may be due entirely to original deposition on a sloping surface or in part to minor subsequent uplift. If subsequent uplift occurred, that may also have been a factor in the rejuvenation of the stream and the formation of the intrenched meanders.

There is a very noticeable parallelism of the smaller streams both north and south of Axial Basin. The writer has observed numerous exposures where the sandstone of the Mesaverde formation is traversed by a very pronounced system of parallel joints. The joints in most places appear to have been developed almost at right angles to the strike of the formation, especially where the beds are dipping rather steeply. This is well shown in Plate XXI. As the courses of the smaller streams are nearly at right angles to the strike of the Mesaverde formation, it is quite probable that they were determined to a considerable extent by the existence of joints.

Published descriptions indicate that the structure of Junction Mountain is not unlike that of Juniper Mountain. The map prepared by White ${ }^{1}$ shows the Browns Park formation as a continuous belt extending from Yampa [Juniper] Mountain to the western border of Browns Park. It surrounds the Paleozoic beds of the Junction Mountain uplift. Powell, ${ }^{2}$ in his structure section through Junction Mountain, shows the Browns Park formation as lying about 500 feet below the older beds where the mountain is traversed by Yampa River. The Browns Park formation, where it laps over the Mesaverde formation, about 5 miles southeast of Junction Mountain, is mapped by Gale ${ }^{3}$ at an elevation that is about 650 feet higher than that of the older beds at the canyon as shown on Powell's atlas map of the Uinta Mountains. These facts strongly suggest that at one time the Browns Park formation entirely covered at least that portion of Junction Mountain through which Yampa River cut its deep canyon. The fact that the present channel of the river is in the Browns Park formation through the entire distance from Juniper Mountain to Junction Mountain, together with the probability that the Browns Park beds at one time completely covered that portion of Junction Mountain including the canyon, certainly justifies the conclusion that this portion of Yampa River also established its course subsequent to the emergence following the deposition of the Browns Park formation.

${ }^{1}$ White, C. A., Geology and physiography of a portion of northwestern Colorado and adjacent parts of Utah and Wyoming: U. S. Geol. Survey Ninth Ann. Rept., Pि1. LXXXVIII, 1889.

2 Powell, J. W., Report on the geology of the eastern portion of the Uinta Mountains and a region of country adjacent thereto, p. $10,1876$.

3 Gale, H. S., Coal fields of northwestern Colorado and northeastern Utah: U. S. Geol. Survey Bull. 415, Pl. XVIII, 1910. 


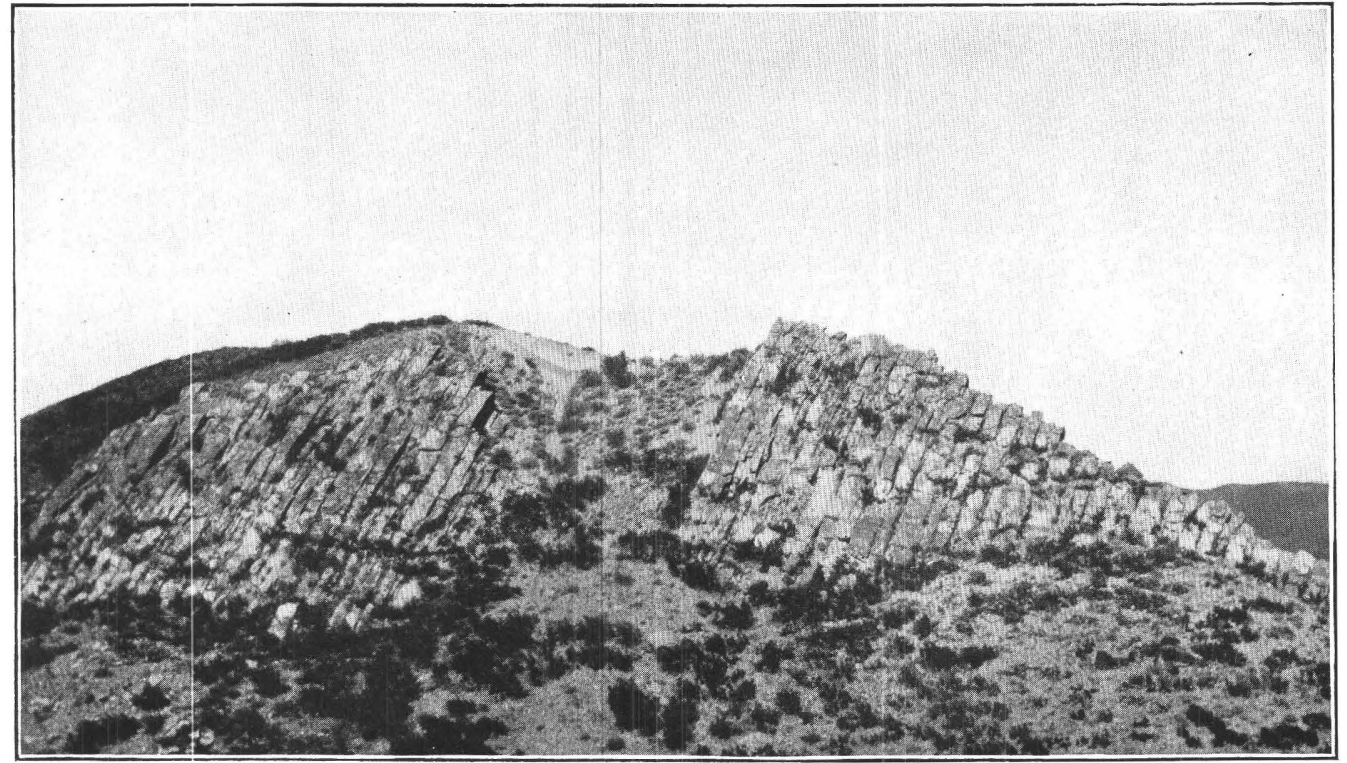

$A$.

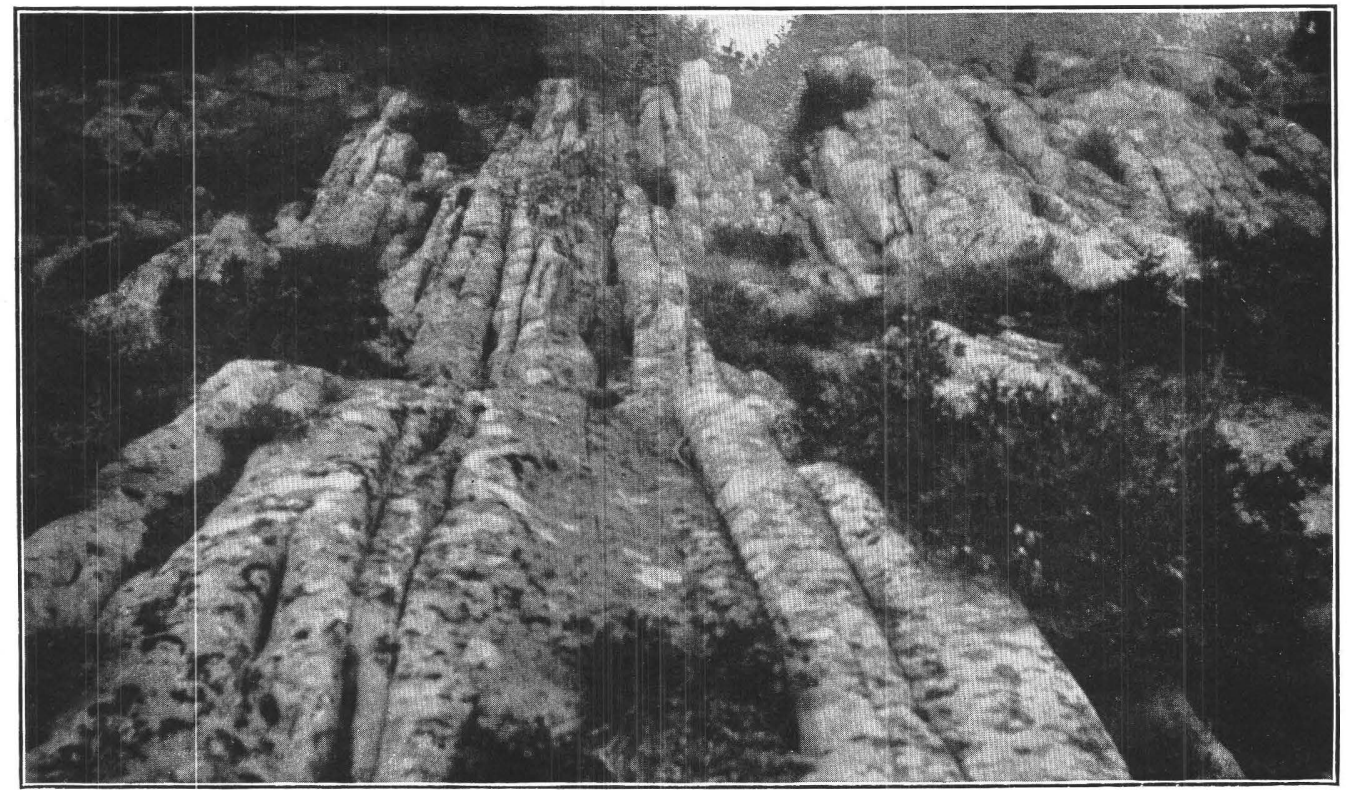

$B$.

JOINTING IN SANDSTONE OF MESAVERDE FORMATION.

$A$, At the "Transfer," T. 2 N., R. 92 W., Meeker quadrangle, Colo.; B, In T. 4 N., R. 91 W., Monument Butte quadrangle, Colo. 

As regards the course of Yampa River from this point to Green River, and of Green River itself, no suggestions based on personal observations can be offered. However, those who have studied the Uinta uplift, including Powell and Emmons, agree that the uplift began at the close of the Cretaceous period, and that later at least 8,000 feet of Tertiary sediments, derived in part, if not wholly, from the degradation of the arch itself, were deposited along both flanks of the range. Accorcling to Powell, these Tertiary formations bent down, while the older beds were uplifted. The present course of Green River for a distance of about 30 miles through Browns Park is in the Browns Park formation. In view of these facts, together with the conclusions which have been reached relative to the origin of one of the principal tributaries of Green River, it is believed that the assertions of the antecedent origin of Green River should be accepted only after more facts have been obtained bearing on the original extent and thickness of the late Tertiary formations, as well as on the diastrophic history of the Uinta Range. 